\title{
Literary Internet: Online Criticism and Literary Communication
}

The advent of the Internet in Poland dates back to $1991 .{ }^{1}$ The past three decades have shown that the cultural changes initiated by this new medium have affected literary criticism more than literature. We are witnessing a spectacular decline in the status and authority of critics, whose role and influence in the digitized environment has been reduced to almost zero. Five years ago, Krzysztof Hoffman reassured literary critics that they "do not have to adapt to the new digital world (not yet), although accelerating changes in cultural circulation will oblige them to take a position" (Hoffman 64). It seems that the moment has arrived when critics have to consider the digital media; otherwise their voice will cease to be heard. Hoffman rightly observes that: "The institution of literary criticism is directly connected to the institution of literature and its ... ${ }^{2}$ medium. In other words, literary criticism as we know it belongs to print culture ..."

This is a very important observation, because each medium determines the form communication takes. The Internet is changing its specificity in a rad-

1 A detailed history of the Internet in Poland is presented by Dariusz Baran in "Internet w Polsce."

2 An ellipsis was used here by the author as a way to build tension. I have replaced it with an ellipsis in parentheses to indicate that I have omitted this punctuation mark, which greatly alters the tone of the comment. 
ical way. However, the second part of Hoffman's statement about critical literary blogs seems too general:

blogs in this perspective are not literary criticism, because their environment is not printing, but digital reality. If we are witnessing the dethronement of paper books and the ascent of e-books..., new forms of participation in the conversation about literature should emerge with them.

Firstly, it is hard to agree with the author's contention that e-books will replace the printed book. Secondly, Hoffman incorrectly defines the essence of media transformation. The problem is not digitized literature that is read from the screen (i.e. the mentioned e-books), because it poses no threat to the printed book at all. The medium from which we read literature (whether it is a page in a book or a screen on an e-reader) does not affect the ontology of the literary text as long as it is only a vehicle for transferring words, although it undoubtedly transforms our perception. What is important is the fact that the medium determines the shape of literature, affects its form (structure) and its ontology (what a literary work is and how it exists), and thus significantly changes the entire model of literary communication. Therefore, though Hoffman rightly observes the need to develop new forms of critical literature dealing with online media, he incorrectly indicates the source of this need. Literary critics have to accept the Internet not because we read more e-books, but because the Internet has become an area in which a literary scholar finds a transformed, sometimes unrecognizable, subject of his research. This is also were a critic will encounter completely new readers who are still interested in literature. Therefore, it is not about deciding whether a blog is or is not a form of literary criticism (in my opinion it may be), but about drawing conclusions from the fact that it is a much more effective form of contact with the reader than the columns of a literary magazine. These are becoming a rapidly depopulating reserve of experts, visited only occasionally by readers.

We have to accept that the new reader, brought up in multimedia culture, reads differently. This is well illustrated by the reaction to Przemysław Czapliński's one literary critique published in 2014 on lubimyczytac.pl about Paweł Huelle's Sing the Gardens. In addition to a few voices praising Czapliński's interpretative mastery (obviously expressed by representatives of the older generation, as evidenced by their enthusiastic comments: "Hats off! ... To the young readers of this website-read and learn :)"), one can find the following com- 
ments: "I can't write like this and I wouldn't like to be able to," "If I were interested in reading a review of this book and if this was the only one on the whole Internet... I wouldn't read it. I wouldn't have enough time. Neither would I want to" (Czapliński). The quoted statements illustrate the total disparity between the expectations and needs of Internet users and readers of traditional literary criticism. Such categories as the economy, clarity and unambiguity of the message are also the criteria by which we can ascertain the usefulness of internet criticism, which is not only meant to clearly present and justify the strong points and flaws of a work of art, but to provide a clear answer to the question of whether a book is worth reading. If typical readers (amateurs who read books in their spare time), that is, the majority of readers, find time to read books, they will certainly not devote any of it to reading such expert opinions. There is no time and inclination.

The irreversibility of the changes described above is a foregone conclusion. Cultural, social and psychological changes that have already taken place and which will undoubtedly continue under the influence of the Internet are not conducive to in-depth analysis and reflection. Perhaps, therefore, we have to come to terms with the fact that literary criticism has become the metalanguage of experts without much social significance and influence.

However the fate of traditional criticism unfolds, it is impossible not to notice that a vibrant area of online literary active is taking shape alongside it. Literature is developing outside the print medium, with which it is mainly associated. If we agree that the invention of printing in the fifteenth century revolutionized the development of literature, by making the production of books cheap and accessible, it will not take a great leap to acknowledge that a medium as ubiquitous as the Internet, where most of the content is free of charge, has had an even greater influence on the shape of literature, its production, dissemination and reception. Today, the Internet, which is ontologically on par with offline reality, has provided a space where new hyper-, quasi-, para- and post-literary writing practices are rapidly developing.

When writing about literary communication on the Internet, I have in mind very diverse and often unexpected ways of referring to the category of literariness. For the purpose of these considerations, I would like to adopt a fairly general understanding of literature as a practice of utilizing language, one that, intentionally or not, goes beyond its purely functional use. Such a definition inevitably invites an association with Jakobson's category of poetic function as an ordering principle of surplus signification. Unlike formalistic and essentialist assumptions, the approach proposed here, despite superficial analogies, is definitely closer to the relational position (neopragmatic, especially post-con- 
structivist), reflecting more adequately the situation of online literature, where often the complex context and the reader's attitude determine the literary status of a given statement. Refining this definition any further would require referring to methodological issues, which I am trying to avoid in these considerations. Given their diversity, it is difficult to find a set of characteristics that would encompass all the practices connected to the terms literary Internet and online literary communication. Some of them are quite traditional narrative forms, such as fan-fiction or Facebook stories, others are writing practices that verge on literature, journalism and metacritical reflection (like some blogs), while others are avant-garde experiments that are self-aware and sometimes present very radical attempts at redefining literature. They often cross the boundaries of literature towards hybrid and multimedia forms and are created thanks to the advanced use of digital technology. They create a rich and diverse area of electronic literature that is constantly developing and diversifying. However, this does not fit into the field of my interest concerning so-called digitized literature, i.e. electronic versions of printed works (e-books, PDFs) or of works whose properties (ontological, epistemological, pragmatic) would not change after printing.

All the mentioned cases are connected by the fact that they arose in a digital medium and are realized in this altered site of communication, thus opening up new developmental perspectives for literature. Thanks to the Internet, writing and reading are no longer the same.

This text is largely a collection of questions and doubts that I ask myself when thinking about online literature and online literary communication, and, above all, about the competences and possibilities of literary criticism, which should keep pace with the changes in culture and literature. I would like to present an abbreviated account of them in an attempt to constructively outline a new way to analyze the kind of literature that is developing online. It should also be mentioned that I will not attempt to reconstruct the state of Western research, which is much more advanced than in Poland in terms of both theoretical and critical literary reflection as well as creative activities. I will focus instead on the state of Polish research and on the main areas of interest of digital literary scholars, who, of course, draw on the findings of Western researchers (e.g. Jay David Bolter, Aspen Aeresth, Richard Grusin, Katherina Hayle, John Cayley, Alan Sondheim, Stephanie Strickland, Rita Raley, Matthew Kirschenbaum and many others), but adapt their research to their native realities and possibilities. These digital literary scholars, who are incidentally also often creators and authors in their own right, are dedicated to promoting electronic literature and explaining its properties and specificity. 
Lev Manovich's ${ }^{3}$ classic definition of digital media allows us to indicate the main differences between printed literature and digital literature (electronic, online). Manovich considered numerical representation, modularity, automation, variation and cultural transcoding to be the features of new media. What this means is that every digital object is written in a mathematical language and can be subjected to algorithmic processing. Digital objects are created using programs, templates and scripts. They also propose a kind of matrix that defines the limits of a writer's and recipient's freedom, as they are always dependent to some extent on the programmer's project. That is why digital works are more often created as collaborative works, co-created by computer science, graphic artists and writers. In the West, the author is usually also a programmer, and in Poland digital authors are increasingly also specialists in digital technologies. Because the digital object (hypertext, animated poetry, generative poetry, etc.) gives the reader a wide range of possibilities in how it can be brought to life (course of action) in the act of reading, the number of possible versions of such a "concretization" is sometimes very large, which makes the digital object appear to be fluid and infinitely variable. Of course, the reader/user only seemingly has unlimited freedom to decide on the shape of the work; in fact, it is the author who decides how much creative freedom to give the reader. A digital object is a kind of musical notation, which materializes in various versions with each interaction. It is also important that thanks to digital media the narrative, considered until recently a natural cognitive structure, has gained a rival method of organizing information - the database. It has become an independent cultural form, one that creates a new model of the world and human experience, while also transforming perception. This is worth remembering, because multimedia structures also affect literary communication. And finally, last but not least, we are dealing with two layers with regards to digital objects: computer and culture. The former, based on mathematical rules, influences the latter, which under the influence of digital ontology, epistemology and pragmatics, develops new genres, new organization of content and new content. Discrete signals (bits of information) of no significance in themselves, decide on the properties of the cultural layer available to the user. This is an extremely important fact for the researcher of digital literature, although they are reluctantly taken into account by humanities scholars, mainly due to insufficient competence in the field of information technology.

In the field of literary studies, poststructuralism questioned the essentialist definitions of literariness, and in the deconstructive approach, the text

3 See Liev Manowich’s Język nowych mediów. 
is viewed as an unstable network of sense-productive signs. The appearance of the Internet, according to many, has brought about a radical blurring of the margins of literature and other forms of non-verbal communication. For this reason, the term "post-literature" is used to define it, a term which, on the one hand, indicates its roots, but on the other, embeds it in the context of contemporary problems of defining phenomena, arts and disciplines. The Internet, as a hypertextual multimedium, dematerializes products which were previously composed of various substances. Because it is digital, it can combine objects previously belonging to different codes into one message. In addition to verbal language, images, sounds, movement have become part of literary communication. Also, if we consider the visual-sound component of language to be a basic building block of literary communication, then in digital works, each such elementary signifier (phoneme, morpheme or meme) is founded on an invisible digital substructure, numerous bites constituting a basic unit of information, an amount so immense that it defies negotiation and interpretation. Whatever it is we are looking at on the screen is written in binary code. In other words, every sign on the Internet has its cultural and technological dimension. Usually, when we look at the screen, we focus on the external, cultural layer of the content: words, images, sounds, their connections, relationships, and references. We interpret what appears on the computer screen in accordance with literary and critical standards, paying due attention to every detail. As humanities scholars, we focus not on system activities but on the semiotics of the message. What constitutes the foundation of the visible, its hidden mechanisms, remains invisible to us.

By not addressing computer technology as the foundation of modern communication, including literary communication, we are, perhaps deliberately, evading the important problem of online literature. We are hiding from view the uncomfortable, unknown, and incomprehensible. Omitting the programmable layer of content obscures our knowledge about the work, rendering it incomplete and perhaps even false. However, accessing code requires familiarity with programming language (such as html), which remains rare among humanities scholars and literary critics. Unfortunately, without knowledge of design software, HTML, and rudimentary technical principles of the Internet, a literary scholar finds oneself in the world of digital texts much like an early twentieth century anthropologist in the Amazon jungle. Here, perhaps, lies the reason why conservative lovers of literature are so suspicious of new literary developments. Ignorance of the mechanisms responsible for the creation and existence of e-literature bars critics from going beyond the cultural layer of a communicated idea, thus risking a superficial reading, one that is at odds with the inherent rules 
of the work and misses the essence of such developments; or it can encourage the critics to develop their competence to include the basics of programming.

All the features of the digital work briefly discussed above redefine the role and place of the reader. Researchers typically point to interactivity as a feature that distinguishes electronic literature from printed literature. It seems useful to make a distinction between interactivity (interaktywności) and interaction (interakcyjności). The first is a feature of an electronic object and consists in the user receiving information and responding to it. This is how all computer games work, requiring the player's activity to start and operate. A significant part of electronic literature is interactive: without particular actions on the part of the reader (clicking on a link, entering a command, selecting one of several possible options) it remains unavailable. However, interactivity is a feature of a digital object, i.e. a program, electronic equipment, and applies to human-machine relations. To describe the interactions and reactions of people participating in the type of communication enabled by digital devices, I would use the term interaction. Thus, social media and the attendant writing practices are based on interaction, that is, on the mutual, dialogical interaction of the sender and the recipient via the medium. The sender posting a comment, meme, GIF or tweet awaits the reactions of the recipients. The appearance of new information is treated as an invitation to comment and exchange thoughts, often reconfiguring this information in a creative fashion. In this way, the model of virtual communication based on interaction is realized.

The beginnings of electronic literature date back to the 196os, when computer-programmed poetry appeared in the United States. It was followed by literary hypertexts, first created in special programs (StorySpace) and saved on floppy disks, and then on CDs. The next stages of the development of hypertextual literature, available online since the 1990s, brought with them hybrid multimedia forms created using more advanced graphic programs, including simple animations, voices and sounds in the narrative. In Poland, the first hypertext appeared in 2002 (Sławomir Shute's Block), and in the twenty-first century came the development of other forms of e-literature that had appeared in the West a dozen or so years ago. On the Electronic Literature Organization website, operating since 1999, one can find a fairly comprehensive list of various electronic literary work, such as the following:

- hypertextual fiction and poetry, available both offline and online,

- kinetic poetry created in Flash or another program,

- computer installations that require the recipient to read or contain other literary aspects, 
- bots, known as computer persona capable of conducting conversations with the user,

- interactive fiction,

- literary applications,

- text, email and blog novels,

- poems and prose generated by the computer, often interactive,

- collaborative work, enabling readers to co-create the text,

- literary online performances that develop new ways of writing.

This list is constantly expanding with new genres, which are published in subsequent volumes of online e-literature. Even now to this list we can add code electronic literature, which combines computer code with the natural language. E-literary genres also include e-mail novels, cell phone novels, geonarratives (i.e. GPS narratives assigned to places), literature for mobile devices, which combines real space and virtual narratives, and interactive drama, also available in the online version. Most of these genres are not known in Poland, and some of them only appeared a few years ago, mostly thanks to Mariusz Pisarski, a writer and promoter of e-literature in Poland. Promoting this type of Polish creativity are poets from the Poznań group Perfokarta with Roman Bromboszcz at the forefront, the group Cichy Nabiau and Resolution Chleb, which included Leszek Onak, Piotr Puldzian Płucienniczak, Łukasz Podgórni and which, after seven years of activity, ceased operations by the end of 2018 .

The latest, third volume of ELO from 2016 includes for the first time four Polish works: Zenon Fajfer’s Ars poetica, Józef Żuk Piwkowski’s Księga Słów Wszystkich (The Book of All Words), Katarzyna Giełżyńska’s $C($ ) $n d u$ it, as well as Tiger's Eyes - a digital adaptation of Tytus Czyżewski's poetry by Urszula Pawlicka and Łukasz Podgórni. Electronic literature requires from its creators a considerable degree of literary awareness and technological competence; it tends to be experimental in form and many of its achievements are referred to as cyber-avant-garde. It is impossible not to notice that this work occupies a niche in Poland, with its low level of popularity resulting from it being difficult, demanding, and incomprehensible. Literary scholars have been reluctant to venture into digital literature, preferring rather to cultivate their attachment to the printed medium, thereby demonstrating that the criteria they use to asses the value of a literary work remain unchanged; however, the reason why digital literature today is cognitively attractive is primarily because it broadens the field of literature by introducing a technological aspect, previously unknown to literary scholars, and disciplinary; electronic literature is what film was a hundred years ago, an interdisciplinary and intermedial phenomenon. 
Because these works are dynamic, impermanent and multi-variant, they require a process-based approach. This exposes the inadequacy of classic textual theories in approaching work that is not an object but an event. Entangled in a network of various social and technological conditions, these works appear as a dynamic weave of many variable factors, as a network of relations and contingencies, rather than a ready-made text that can be critically reviewed. They gain meaning in interaction, i.e. when interacting with devices, recipients, but also with the cultural environment in which they are received.

In addition to electronic literature, many new, though still traditional, writing practices are being developed online. They are based on building a narrative, they use clear references to printed works, often imitating traditional conventions and using proven techniques of constructing characters and plots taken from literature.

Social media is credited with giving rise to numerous, though not easily classifiable, genres, some of which have gaining a large (measured by the number of likes and the number of observers) group of loyal readers, who follow and comment on subsequent entries. These works are based on collective activities and the interaction of users of websites and digital platforms, who influence the shape of the work being created. Here you can find blogs that flourished before the age of Internet 2.0, as well as Facebook literature, tweeterature, fan-fiction; these are accompanied by a new form of literary criticism, prevalent in the Polish fan community, practiced by amateurs on websites called analizatornie. The latter are developing as a new form of critical and creative reading and writing.

While the two earlier categories can easily be identified as developing from the literary tradition, the next one includes liminal forms derived from various semiotic codes. This is where we can find memes, GIFs, copy-pastes, i.e. liminal forms, referred to as logo-visual literature. These are multimedia expressions that have developed in cyberspace, though they are very often also found in the literary tradition. They refer to this tradition and from it they draw their power to generate meaning and critically comment on events. What makes these forms different from electronic literature is their immersion in cyberspace and functional communication, much greater adaptability and no clear declaration about the author's literary intentions. This classification is imposed against the intentions of the creators, who simply play with the possibilities of software, comment on current events, and inadvertently involve in these communication experiments language that becomes one of the means of artistic expression. For these hybrid uses of literary language, which combine functional language and visual messages, we should reserve the term post-literature. 
Internet literature, in its various transformations and variations, is developing independently of offline literary life, which is controlled by the market, over which one can exercise some measure of institutional control on account of existing publishing laws. The new media reality entails new possibilities, a new sensitivity and new expectations with respect to the offered content and to those who comment on it. That is why, next to writers who publish books (more often also in the form of an e-book), a great number of amateur authors begin writing without feeling the need to enter into the models of literary life established during the printing era. The publication of a book, a volume, or a collection of stories is no longer something that elevates the status of an author, at least that is what they claim. Although the symbolic status of a printed book still signifies that one is publishing "real" literature, there is a new tradition of literary production that breaks with the institutions and values of the era of print. The world of cyber-literature exists on its own terms and does not need analog culture. Therefore, it does not depend on expert opinions; it rejects the authority of critics. However, let us not forget that critics repay them with the same désintéressement. Having determined that what is digital is less important and less valuable in artistic terms, critics choose not to venture into the abyss of the Internet. What is striking in the statements literary scholars have made about Internet literature is the remarkable conservatism and the inadequacy of their interpretive apparatus (descriptive categories, criteria of analysis) used in relation to these new literary developments. The medium is not only a medium that provides the recipient with text, but also technology that affects the structure of the work and the communication situation, which literary scholars do not always want to remember. Here the apparently conservative attachment of literature studies to the printed book is revealed.

From the beginning, the Internet has been a medium with literary potential. Some scholars even believe that its nature is fundamentally literary. This is interestingly demonstrated in Sandy Baldwin's book, The Internet Unconscious. On the Subject of Electronic Literature. Applying a psychoanalytic lens, she shows how electronic literature, which includes all Internet users without exception, is conducive to the emergence of new writing practices. Due to the properties of this medium, the communicative situation, in which we participate every time we write an e-mail, tweet, create a status on Facebook, or even log in to a website to gain access to information, has outstanding literary potential. Baldwin defines literariness very broadly, in the spirit of deconstructionism, as openness to the experience of mystery, encounters with the unknown, unexpected and unpredictable. What is more, the desire for this encounter is inscribed in the forms of activity we undertake, and the uncertainty as to the identity of our 
interlocutor only intensifies the creative potential of this medium. It is worth appreciating the value of this concept, which exposes the status of a logged-in subject actively participating in cyberspace. Psychoanalysis allows us not only to describe the structuring of fantasy (unconsciousness) and the identity (auto) creation games of virtual entities, but also to answer the fundamental question of the humanities: the condition and anthropological status of an active network user, entangled in the complex dependencies of the programmable medium, of its recipients and of the creators behind it.

The perspective proposed by Baldwin is one of the many from which online literary communication is today critically reviewed. There is no doubt that the medium, which is little over a quarter century old, has created a new environment, and not just for literary experiments. Literature has undergone a profound transformation in the digital environment; moreover, its subject is not identical to that of analog literature. Literary phenomena developing online are the result of a deep ontological transformation, obviously related not only to technological changes but also the following: cultural, anthropological and sociological. The traditional roles of the author, reader, critic, editor have been transformed, and sometimes destroyed. Amateurs are not only creators, but also editors, proofreaders and publishers of their work, which for obvious reasons affects its quality. It should also be remembered that creators and recipients using the Internet have also been influenced by it: their perception, sensitivity, and ability to think critically and reflectively have changed. It is worth bearing in mind this ubiquity of these transformations. For the record, let us add that this metamorphosis concerns not only literature, but the status of all art, to such an extent that it seems difficult to maintain the definition of literature as a monomedium, i.e. a message created in a verbal language. Therefore, if even the word as an unquestionable criterion for recognizing literature has ceased to be its determinant, is it still possible to distinguish literary works from, on the one hand, net art and, on the other, ephemeral functional texts? And are the distinctions and categories (also genological) used in the world of analogue texts applicable to online literature?

The above remarks lead to the separation of two separate but related phenomena. We are observing changes in the condition of literary criticism that are taking place as a result of cultural changes, with the Internet being the main impulse. However, at the same time, changes have taken place in the nature of literature itself, which has expanded to include various e-literary projects available online, as well as forms of writing activity practiced on social networks. At the same time, its ontological clarity has weakened, because literature 2.0 should not be associated solely with words. 
In the publication announcement of The Digital Critic. Literary Culture Online (edited by Houman Barekat, Robert Barry, David Winters ${ }^{4}$ ), which was published at the end of 2017, the model of traditional literary criticism was cited to illustrate the specificity of online literary culture. At the end of the twentieth century, this traditional model was still going strong: it developed within a paradigm characterized, according to the publishers of or Books, by several permanent determinants: it was embedded on the foundation of knowledge, objectivity, understood as absolute impartiality and withdrawal of the author, who formulated opinions with due diligence. At a time when the computer served as a typewriter, traditional literary criticism had a largely institutionalized, professional, expert character and occupied an important place in literary life, influencing its canon, its readership, and, indirectly, the tastes of its readers. This brief description of these good times ends with a rather dramatic sentence about its potential: "And then the Internet happened." The development of the Internet rapidly transformed global communication and, as such, exerted influence on literary communication.

It is worth adding that The Digital Critic was published less than three years after a discussion on literary criticism in the era of literature 2.0 was held in London in February 2015. The organizers invited everyone interested to celebrate the "boom of online criticism," and, through the public nature of the event, wanted to encourage "readers to engage in the development of digital literary culture" ("Literature 2.0"). By introducing the concept of digital criticism, they also drew attention to the different way literary criticism approaches online literature. The book, which summarized the history of the literary internet and collected various points of view, both of skeptics and of the creators involved in its development, indicated one thing: that the future will bring further changes in the shape and status of literary criticism, including the risk of its total collapse in the era of Facebook likes, Twitter wars for instant replies and 1,000 character reviews on Amazon.

The organizers of the London panel were well aware of something that is only now slowly reaching the consciousness of Polish literary scholars: that the culture of the Internet, also in its literary aspect, is the domain of cooperation, commitment and co-creation. Readers are not passive recipients (in the sense

4 The list of contributors and editors of the volume does not represent the academic world; they are editors of online literary journals: "Review 31" exists since 2011, the editor-in-chief is Hoiman Barekat, and Robert Barry is the editor of the technology and digital culture department; “3: AM Magazine” has been in existence since 2000, with David Winters as its the editor-in-chief. 
that their activity is not limited to reading and interpreting unchanging works of literature), but are co-authors in the sense that they interact with the author and/or work: they read, comment, share impressions, and the authors willingly engage in a dialogue with them. These authors are well aware of the fact that without committed readers giving them likes, sharing their entries, often conducting inspiring discussions, online work, which has a tendency to rapidly disappear under the flood of new contributions, has no chance for a longer life. This is simply due to the nature of social network sites, where information appears quickly and access to it is fleeting. The popularity of Wattpad testifies to the significance of amateur online creativity. The Polish version of the website states that it is "the largest community in the world for readers and writers." You can post your work there without any restrictions and read what others have written and posted. The popularity of this type of writing service, as well as such social media sites as Facebook and Twitter, which are also sites of literary creativity, shows how diverse this amateur literary creativity is in terms of genres, but, at the same time, how conventional and predictable it is; nonetheless, it is developing extremely dynamically thanks to the possibilities offered by the Internet. This is happening without the help of experts, critics and editors. The readers are the reviewers. This concept of new communication is clearly visible on fan-fiction websites, where communities of specialized experts gather to continue, reconfigure and develop their favorite works of fiction.

Genres such as blogs, fan pages are disregarded from the perspective of printed criticism. Serious researchers do not read the opinions expressed there, and it is also rare that a literary scholar runs a critical literary blog (exceptions include younger and middle aged critics, such as Bernardetta Darska, Jarosław Czechowicz, Paulina Małochleb, and Justyna Sobolewska). Digital forms are still regarded as inferior, less valuable. A printed publication, with its system of editorial-publishing-reviewing procedures, is a guarantee of quality. As a result, a widening gap between the two circulations can be observed: print circulation and the world of online communication (also literary) that is composed of numerous independent communities, located ahierarchically, often vertically. The Internet is replete with websites dedicated to books, where anyone can share their opinion and review the text. Institutional and technical barriers and restrictions have disappeared. For this reason, the world of literary criticism is increasingly moving away from the realities of online culture, which is a culture of sharing and exchanging texts, opinions and values.

The clash of these two types of sensitivities, these two models of literature and two incompatible ways of talking about literature can be illustrated with the example of two statements. The first is from an article "Co słychać?" by 
Zofia Król, published in dwutygodnik.pl, a peculiar cornerstone of traditional literature studies and academic criticism on the Internet. Zofia Król, its founder and editor-in-chief, doctor of philosophy, researcher of culture and literature, uses analytical tools taken from classical poetics and narratology to describe new phenomena, including Facebook literature. The second is from Konrad Janczura's op-ed, mockingly reacting to her article, published in the online Ha!art as part of the satirical series Trendy srendy (Janczura). The author is a graduate of the Literary and Art Criticism at the Jagiellonian University, but above all he is the editor of "Popmoderna," a blogger, and a passionate opponent of the existing shape of literary culture.

Zofia Król wrote an article about the new literary genres developing on Facebook. In this article, she lists and characterizes these works, among which are stories about everyday events that authors post on their walls-fairly regular, short, witty posts, usually ending with a surprising conclusion. The author is usually the narrator (Łukasz Najder, Adelajda Truscińska, Grzegorz Wysocki), but the uniqueness lies in the constructed hero, who enchants with folk wisdom, surprising both the narrator and the readers. It is not uncommon, especially when written by professional writers, that they "build up their literariness" and dazzle with linguistic inventiveness (Agnieszka Wolny-Hamkało, Julia Fiedorczuk). Another characteristic element of Facebook mentioned by the researcher is the Facebook article, whose appeal is explained not by topic or style, but by the appeal of the author, who is the main reason why readers follow and like the posts. Król observes that literary columns (Piotr Czerski, Ziemowit Szczerek) often appear first as blog entries, and only then are linked to Facebook. In this case, the blog should be treated as the main platform for the author's statements, while social media provide additional information and serve as self-promotion tools, ensuring that the published content quickly reaches a significant number of readers. However, the opposite is also true: the author first publishes on Facebook, and then moves to blog entries. It also happens that the original Internet publications appear in print, like Julia Szychowiak's Całe życie z moim ojcem, published in 2016, consisting of short, surprising dialogues with her father, known well to her followers on Facebook. Collected in the book, they became a record of epiphanies, but not because of the uniqueness of the dialogues, but because of the communicative situation. Short scenes posted on the empty page of the book astound with the brilliance of the phrases used in the dialogues, which gain depth that is easy to overlook on the Facebook wall.

This transmediality is a characteristic feature of the Internet, which creates spaces through which specific types of creativity can pass endlessly. Someone 
who has a blog simultaneously communicates with an audience through other channels, and very often these take the form of supporting and promoting traditional, printed literature, which in some circles still legitimizes the artist. An interesting and probably the most well-known example of Facebook art is Łukasz Podgórni's Cichy nabiau, where the author posts his mocking comments, metamems, which are understandable to a group of initiated members familiar with his conventions. Król mentions this page in her article, but she does it in a way that invites Janczura's mockery, who accuses her of failing to understand new communication. It should be emphasized that Król meticulously notes the characteristic features of new literary practices on social media, but does so with sincerity: the fact that character limits often affect language inventiveness, and that they result in interesting stylistic effects. The absence of Polish characters, punctuation and inflectional endings, irritating as they may be to conservatives, can have poetic potential. Other features of this new literature are that it is short-lived and transient in nature, it quickly becomes outdated, and it focuses on events happening here and now. The author is also aware that by describing Facebook literature in such a way, she is working against the nature of the medium, and in spite of the expectations of the interested parties themselves:

In any case, it should be remembered that analyzing Facebook posts as literature, arranging them into a series and trying to pick out certain regularities, we are acting against the medium itself. The medium, however, takes its revenge by making us scroll forever to find literature from last year. (Król)

A note about scrolling, i.e. perusing through posts, which Facebook arranges in chronological order; this complicates accessing older entries, which emphasizes their short lifespan and is reminiscent of the nineteenth-century episodic publications in weekly newspapers. The analogy is distant, but it allows us to clearly make the point that each medium influences the content and the cultural practices that it shapes. The author concludes her analysis on the interaction of printed and Facebook literature with an important conclusion that is worth quoting in full:

The medium eliminates the criteria for critical evaluation and the very need for them, though these criteria already find themselves in a deplorable state, as well as traditional literature. At the same time, Facebook posts do a good job at loosing the framework for thinking about 
literature, something which is much needed in public conversation; they also lend themselves well to promoting literature. They demonstrate that the distance between the everyday world, the status of, say, a hard-boiled egg and sausages for breakfast, and the literary statement depends only on the given context. "What's up?" asks the medium, and the answer to this question may already be literature. (Król)

A response to this matter-of-fact text, written from a perspective that is external to the world of social media, is provided by a scathing article by Janczura, who, as he says frankly, "mocking the biweekly is in his blood." The critic attempts, unfortunately without any substantive arguments, to prove the inadequacy of the researcher's tools and how little can be said about Facebook posts if one does not accept the users' perspective and way of thinking. The object of mockery is primarily the "linguistic buffoonery" used by the authors of the online magazine, the so-called "language of discourse." The young author, who had in the past engaged in literary criticism, mainly in the recently defunct magazine Popmoderna, now practices op-ed criticism: subjective, personal, often extraneous. One can, however, extract from his article several characteristic features of the new consciousness shaped by the culture of the Internet. In his polemic with Zofia Król, he assumes that the author behaves like an "uncle at the holiday table" who "blathers on a subject about which he has no clue." Further, the criticism is even more aggressive:

Suddenly the elite critic extends a gesture of mercy towards this lower form of art mushrooming on Facebook. She discovered that a status update can also be considered literature, since it is a genre cultivated by 'real writers', yes, the real ones, meaning those published in print. (Janczura)

It is possible to see here the oft-repeated criticism leveled at institutionalized literature, which depreciates the fledging on-line literature, grants awards to authors of analogue literature, who often have a much smaller group of readers than online authors. Further allegations verge on being abusive. Janczura accuses Król of being ignorant as to the existence of electronic literature and the studies that have been done on it, although Król did deal with the former, but described a particular section of Facebook literature, which, although uses the possibilities of the digital medium, is not the same as e-literature.

Janczura is annoyed by the traditional hierarchical literary system based on artistic value, identifying it with elitism and thus injustice. Formal language 
and the hermetic nature of literary criticism reveal a lack of understanding of spontaneous Internet creativity, which should be written in a "more normal," less sophisticated, and therefore more sincere language. First of all, he emphasizes that Internet creators do not aspire to be published authors in the traditional sense, as they create their own alternative literary circulation, their own communities, and a system of communication (like meme makers, which for the initiated are a multilevel meta-conscious games).

In addition, Janczura juxtaposes Facebook creativity with the alleged passivity of readers of printed literature, whose only activity is to comment on what others have written. On the Internet, every reader is at the same time a creator, copying, pasting, processing, commenting, adding — and this activity is both a way of communicating with others and a form of the most sincere and authentic criticism of culture, one that is based on mutual understanding and sharing. Janczura also criticizes Król for referring to examples of authors who had already been elevated by a book publication, and thus have the status of "real" writers, and for describing Facebook literature in a language that is so at odds with its spirit:

you just have to write, it's what you ought to do, because it is serious humanities. There is no semblance of science there, but literary studies by a capital "L," which should in no way be associated with ass kissing. But, Ms. Zofia, why do you respect only real writers on Facebook: Fiedorczuk, Wolny-Hamkało, Najder, Szczerk or Klicka, if, for example, Ola Radomiak from Piotrków Trybunalski is doing so well on Facebook? Ola has not yet published a book, but has collected over 50,000 likes for her efforts. (Janczura)

The confrontation of these two points of view shows that the community of Internet creators, represented here by Janczura, ostentatiously dissociates itself from the official institutions of literary life, along with the hierarchies and assessments they legitimate. It creates a new, ahierarchical space of communication, in which the publication of a book is not a status symbol (though Janczura's own path from online publication to his own printed novel seems to belie such an approach), while the voices of analog critics are treated as evidence of anachronism and lack of understanding of the elementary differences between the world of the Internet (in which lively, dynamic, interactive literature develops) and the world of print, which preserves the old model of writing that is incompatible with the sensitivity and needs of new generations of Internet users. 
The short polemic summarized above exposes the greatest weaknesses of online writers, who create a closed subculture that does not recognize voices other than those from other users. Social media has brought about changes in the mindset of readers of literature. They are now characterized by much greater candor, spontaneity, and the belief that immediate contact between the author and the reader is natural and desirable. In turn, the lesson for researchers and critics trying to reflect on the world of digital literature is that traditional criteria for analyzing and interpreting a work must be extended to include knowledge of the media history and theory and mediology. It is worth suspending judgment and approaching these new forms of literary practice without prejudice, because the sociological and psychological dimensions of these practices are as important as the linguistic exploits in recognizing the new position of online literature. There is no doubt that, from the perspective of the time-honored aesthetic canon, most of the works created online are much less mature and artistically inferior to a standard printed book. However, this should not be stated in the research on online literature. The cognitive dimension of these studies is important. The idea is to better understand the essence of the changes taking place in culture, communication and literature. A thorough and comprehensive description of these developments will yield interesting revelations and insight: also about the condition of literature in the Internet era. Internet literature is not, much like analogue literature, an isolated artistic field, but part of social life. It serves to share views, emotions, and to inspire to action. In this sense, life and literature intertwine intensely, and the classic categories of fiction and originality cease to fulfill the function of organizing and categorizing the different categories of writing. There are quite a few tools to choose from: those developed by psychoanalysis, allowing you to say something about the subject, cultural studies tools, showing cultural changes through the activities of e-literature creators. Mediology raises questions about the role of the medium, which is not only a carrier and a transmitter, but an important part of our communication, changing it and us. Sociology provides empirical data about the number and specificity of online communities, although research is quite difficult here because of the anonymity and dynamics of the Internet. Phenomenology, semiology, anthropology, reception aesthetics; all these disciplines and methods can now be reflected in a new mirror and their usefulness can be rediscovered. The sociology of science practiced by post-constructivists offers ready-made tools, among which the concept of the author-network (ANT-theory) has already found its application in the study of networks. ${ }^{5}$

5 See Bruno Latour's Reassembling the Social: An Introduction to Actor-Network-Theory. 
Digital literary projects are an answer to cultural changes. The print medium - static, flat, unchanging, presuming passivity and subordination-is no longer able to compete with the new possibilities of digital technologies. That is why literature is not so much dying as it is adapting to the new reality. Digital literature is emerging in much the same way as the avant-garde, which had once tested the limits of expression and communication; today digital literature tests the endurance and competence of readers.

Many of the comments made here are regarded as obvious in the world of digital humanities, but, nonetheless, still merit repeating. With the development of e-literature, there is a noticeably widening division between literary scholars into analog literature researchers and those who recognize the Internet as a new medium of literary practice, one that is significant, inspiring and brimming with important innovations for literary scholarship. Engaging in digital literature requires a literary scholar to abandon many fundamental assumptions about literary research, such as the stability and material permanence of the subject of this research, which has been replaced by the dynamism of digital objects; copyright protection from outside interference, which has largely been annulled by interactivity and a readers' interference into the work as a condition for its existence; perception and understanding of information technology, text-forming mechanisms functioning behind the literary work, which repeatedly exclude a hermeneutic focus on the semantic layer of the message and interpretation as the main cognitive goal; structural continuity, which has been replaced by modularity, etc.

Furthermore, when researching these new phenomena, it is difficult to clearly draw the boundary between a historical and critical literary perspective. The online literary communication that we are interested in is little more than twenty years old in Poland, and as such it is part of modern day life. It is, however, worth remembering that digital literature, on account of its dependence on rapidly developing technologies (new software entail new possibilities), makes it more susceptible to obsolescence than is the case with analog literature. In addition, but also in connection with this, most critics following these new literary developments preserve and recall the historical perspective as a necessary means to explain the specificity of e-literature. This means that we are still approaching these developments from a dual perspective: as those that design the future of literature, culture and civilization (although it is difficult to say that it is the future of literature-contrary to skeptics, it cannot be said that analog literature will be replaced by digital literature), while, at the same time, they talk a lot about the tradition they come from, which they often negate, transform, but never ignore, because the innovations presented as literary 
necessarily evoke the context of printed literature. Each digital work exists for a literary scholar by reference to a model of analogue culture and literature. This position of the commentator, which is external to the literary Internet as it exists for its users, is obviously a major flaw. Unlike clearly defined and separated roles in the analog world, an e-literature researcher and critic is very often also its co-creator and culture animator.

Mariusz Pisarski, a researcher, creator, commentator, and digital humanist, is an excellent example of a critic who has followed the transformation of e-literature. Another researcher from the youngest generation, Urszula Pawlicka, has adopted a very similar strategy of managing literary life. We should also add Piotr Marecki to this list, the most experienced animator of digital literary culture, editor-in-chief of "Ha!Art." Literature scholars who approach these new developments from a perspective of cultural and literature history are also precursors of electronic literature research: Maryla Hopfinger and Ewa Szczęsna, Małgorzata Janusiewicz, Agnieszka Karpowicz, Agnieszka Przybyszewska, Dorota Sikora, Monika Górska-Olesińska, and Anna Gumkowska. These researchers do not have critical literary aspirations. It is not difficult to notice that cultural studies play a dominant role in the research on media transformations: Ryszard Kluszczyński, Wiesław Godzic, Mirosław Filiciak, Marek Krajewski, Piotr Celiński, and Tadeusz Miczko. This is explained by the extraordinary popularity of culture sciences, which is largely due to the transdisciplinary or even post-disciplinary nature of contemporary humanities. Cultural experts, as opposed to literary scholars, tend to be much more open to new digital developments in the world of culture.

That is why one of the more known and respected American critics and researchers of electronic literature, Katherine Hayles, ${ }^{6}$ believes that there is a need to establish research teams that will critically explore the cognitive, aesthetic, ontological, functional, communicative, sociological, anthropological, perceptive, economic, cultural and all other consequences resulting from the emergence and development of programmable hybrid literary practices in the digital medium. Entering the posthumanist space of cooperation between people and machines still remains in Poland a future perspective.

\section{Translated by Marcin Tereszewski}

6 See Katherine Hayles' How we Became Posthuman. Virtual Bodies in Cybernetics, Literature and Informatics. 


\section{| References}

Baldwin, Sandy, The Internet Unconscious: On the Subject of Electronic Literature. Bloomsbury: Bloomsbury Academic, 2015.

Baran, Dariusz. “Internet w Polsce." Polski system medialny 1989-2011. Ed. Katarzyna Pokorna-Ignatowicz. Kraków: Oficyna Wydawnicza AfM, 2013. 75-92.

Barekat, Houman, Robert Barry, David Winters, eds. The Digital Critic. Literary Culture Online. New York: or Books, 2017.

Czapliński, Przemysław. "Ekstaza i przemoc." lubimyczytać.pl, https://tinyurl. com/y8enj9k3. Accessed 25 September 2017.

Fajfer, Zenon. Ars poetica, https://tinyurl.com/y9bkb4bu. Accessed 28 September 2017.

Giełżyńska, Katarzyna. C()n du it, https://tinyurl.com/yaylobtw. Accessed 28 September 2017.

Hayles, Katherine N. How we Became Posthuman. Virtual Bodies in Cybernetics, Literature and Informatics. Chicago-London: The University of Chicago Press, 1999.

Hoffman, Krszysztof. "Hejtuję litblogi? Blogi o literaturze a krytyka literacka," Literatura w mediach III. Nowe wizerunki. Eds. K. Taborska, W. Kuska. Gorzów Wielkopolski: Wydawnictwo Naukowe Pwsz w Gorzowie Wielkopolskim, 2014.

Janczura, Konrad. Trendy srendy (4): Witamy w dwutygodniku, https://tinyurl. com/ybjkf83k. Accessed 28 September 2017.

Król, Zofia. "Co słychać?” dwutygodnik.com, https://tinyurl.com/yc8uwlts. Accessed 28 September 2017.

Latour, Bruno. Reassembling the Social: An Introduction to Actor-Network-Theory. Oxford: Oxford UP, 2005.

"Literature 2.0: Criticism in the Digital Age," https://tinyurl.com/yde5nu83. Accessed 28 September 2017.

Manowich, Lev. Język nowych mediów. Trans. P. Cypryański, Warszawa: waip, 2006.

Piwkowski, Józefa Żuk. Księga Słów Wszystkich, https://tinyurl.com/y9aaxd8e. Accessed 28 September 2017.

Pawlicka, Urszula, Łukasz Podgórni. Oczy tygrysa, https://tinyurl.com/ycpz64al. Accessed 28 September 2017.

Szychowiak, Julia. Całe życie z moim ojcem. Poznań: wBpicak, 2016. 


\section{| Abstrakt}

\section{ELŻBIETA WINIECKA}

\section{Literacki Internet. Uwagi o krytyce i komunikacji literackiej w Sieci}

Artykuł poświęcony jest przemianom komunikacji literackiej w Internecie. Autorka opisuje, jak zmienia się krytyka literacka i jej rola w medium wirtualnym, wskazuje na głębokie zmiany kulturowe będące efektem rozwoju form komunikacji w mediach społecznościowych. Charakteryzuje również przekształcenia literatury, którym podlega ona w Internecie. Za sprawą nowych mediów narodziły się i rozwijają nowe gatunki literackie, ale również sama literatura zmienia swój status, przybierając często charakter hybrydyczny, lokując się na pograniczu sztuki słowa i mediów audiowizualnych. Zachodzące przemiany nie stanowią przy tym zagrożenia dla literatury drukowanej, są natomiast wyrazem siły oddziaływania Internetu na komunikację literacką oraz jej uczestników. Niezbędne są rezygnacja z łatwego wartościowania zachodzących procesów i skupienie się na ich rzetelnym opisie, analizie i interpretacji jako nowej, mało znanej części poszerzającego się pola literackiego.

Słowa kluczowe: literatura elektroniczna; komunikacja literacka online; Internet; życie literackie w Internecie; media literackie

\section{| Abstract}

\section{ELŻBIETA WINIECKA}

\section{Literary Internet: Online Criticism and Literary Communication}

This article is devoted to the transformations that literary communication has undergone on the Internet. The author describes how literary criticism and its role in the digital medium has changed, indicates the deep cultural changes resulting from the development of forms of communication in social media, and characterizes how the Internet has transformed literature. New media has given rise to new literary genres; it has also altered literature itself, recasting it in a hybrid form on the border between the literature and audiovisual media. The ongoing changes do not pose a threat to printed literature, but are an expression of the strength of the Internet's impact on literary communication and its participants. It is necessary to refrain from easy evaluations of the ongoing processes and to focus on accurately describing, analyzing and interpreting them as a new and relatively unknown part of the expanding literary field. 
Keywords: Electronic literature; online literary communication; the Internet; literary life on the Internet; literature media

\section{| About the Author}

Elżbieta Winiecka is Professor in the Institute of Polish Studies at Adam Mickiewicz University in Poznań. Currently, her research interests involve literature in the context of culture, philosophy and the media. She is interested in the relationship between technology and literature, especially in relation to the Internet, remedialization and intermediality of literature. She is the author of the following books: Białoszewski sylleptyczny (Poznań 2006), Z wnętrza dystansu. Leśmian - Karpowicz Białoszewski - Miłobędzka (Poznań 2012). She is the editor of "Poznańskie Studia Polonistyczne. Seria Literacka.”

E-mail: e.winiecka@wp.pl 
